\title{
Addisonia enodis (Vetigastropoda: Lepetelloidea) associated with an elasmobranch egg capsule from the South Atlantic Ocean and the discovery of the species from deep waters off northeastern Brazil
}

\author{
Silvio Felipe Barbosa Lima ${ }^{1,3}$, Luiz, Ricardo Lopes Simone ${ }^{2}$ \& Carmen Regina Parisotto Guimarães ${ }^{I}$ \\ ${ }^{1}$ Universidade Federal de Sergipe, Departamento de Biologia, São Cristovão, SE, Brazil. \\ ${ }^{2}$ Universidade de São Paulo, Museu de Zoologia, São Paulo, SP, Brazil. \\ ${ }^{3}$ Corresponding author: Silvio Felipe Barbosa Lima, e-mail: sfblima@gmail.com
}

LIMA, S.F.B., SIMONE, L.R.L., GUIMARÃES, C.R.P. Addisonia enodis (Vetigastropoda: Lepetelloidea) associated with an elasmobranch egg capsule from the South Atlantic Ocean and the discovery of the species from deep waters off northeastern Brazil. Biota Neotropica. 16(3): e20160202. http://dx.doi.org/10.1590/16760611-BN-2016-0202

\begin{abstract}
A gastropod specimen of the subfamily Addisoniinae Dall, 1882 is reported here for the first time associated with an elasmobranch egg capsule from the South Atlantic Ocean. A specimen of Addisonia enodis Simone, 1996 was found living inside an egg capsule of Atlantoraja castelnaui (Miranda Ribeiro, 1907) (Arhynchobatidae Fowler, 1934) from shallow waters off southeastern Brazil. Previous studies have reported the association of members of the genus Addisonia Dall, 1882 only with the egg capsules of sharks from the family Scyliorhinidae Gill, 1862 and skates from the family Rajidae de Blainville, 1816. Other specimens of $A$. enodis are also here reported to occur off northeastern Brazil based on shells found in deep waters off the state of Sergipe, which fills a gap in its distribution in the Southwestern Atlantic to the north of this region. Addisonia enodis was recognized as a synonym of $A$. excentrica (Tiberi, 1855). However, we consider $A$. enodis as a valid species until further data clarify this issue based on a large sample of Addisonia from Brazilian waters.

Keywords: Gastropoda, Addisoniidae, Addisonia excentrica, South America, deep sea.
\end{abstract}

LIMA, S.F.B., SIMONE, L.R.L., GUIMARÃES, C.R.P. Addisonia enodis (Vetigastropoda: Lepetelloidea) associada a uma cápsula ovígera de elasmobrânquio no Oceano Atlântico sul e a descoberta da espécie em águas profundas no nordeste do Brasil. Biota Neotropica. 16(3): e20160202. http://dx.doi.org/10.1590/1676-0611-BN-2016-0202

Resumo: Um espécime de gastrópode da subfamília Addisoniinae Dall, 1882 é reportado aqui pela primeira vez associado a uma cápsula ovígera de elasmobrânquio encontrada no Oceano Atlântico sul. Um espécime de Addisonia enodis Simone, 1996 foi achado vivendo na parte interna da cápsula ovígera de Atlantoraja castelnaui (Miranda Ribeiro, 1907) (Arhynchobatidae Fowler, 1934) em águas rasas do sudeste do Brasil. Estudos prévios mencionaram a associação de membros do gênero Addisonia Dall, 1882 somente com desovas de tubarões da família Scyliorhinidae Gill, 1862 e raias da família Rajidae de Blainville, 1816. Outros espécimes de $A$. enodis também são aqui reportados para o nordeste do Brasil com base em conchas coletadas em águas profundas ao largo de Sergipe, as quais preenchem uma lacuna em sua distribuição no sudoeste do Atlântico. Addisonia enodis foi reconhecida como um sinônimo de $A$. excentrica (Tiberi, 1855). No entanto, essa espécie é considerada válida, neste estudo, até que mais dados demonstrem com clareza que tratam-se da mesma espécie.

Palavras-chave: Gastropoda, Addisoniidae, Addisonia excentrica, América do Sul, mar profundo.

\section{Introduction}

Lepetelloidea is one of the least investigated groups of marine gastropods, whose species richness is sporadically approached by alpha-taxonomic studies, especially from the South Atlantic Ocean (Simone 1996, Leal \& Simone 2000, Simone \& Cunha 2003, Lima 2014, Lima et al. 2016).

Lepetelloidean gastropods are far from being well known from shallow and deep waters off Brazil, where so far a total of three families and only five species were reported (Simone 1996, Leal \& Simone 2000, Simone \& Cunha 2003, Lima 2014, Lima et al. 2016): Addisonia enodis
Simone, 1996 (Addisoniidae), Copulabyssia riosi Leal \& Simone, 2000, Lepetella furuncula Lima, Guimarães \& Simone, 2016 (Lepetellidae), Notocrater christofferseni Lima, 2014 and Pseudococculina rimula Simone \& Cunha, 2003 (Pseudococculinidae).

Members of the subfamily Addisoniinae are classified into the single genus Addisonia Dall, 1882 (Roldán \& Luque 2010), which was once represented by six Recent species (Dantart \& Luque 1994, Bouchet \& Gofas 2014), but currently only two congeners are considered valid (Roldán \& Luque 2010, Bouchet \& Gofas 2014): the amphi-Atlantic A. excentrica (Tiberi, 1855) (Roldán \& Luque 1999, 2010) and the eastern Pacific (California) A. brophyi McLean, 1985 (McLean 1985, 
Haszprunar 1987, Dantart \& Luque 1994, Simone 1996, Roldán \& Luque 2010). Addisonia brophyi and A. excentrica are biologically associated with the elasmobranch egg capsules (McLean 1985, 1992, Dantart \& Luque 1994, Roldán \& Luque 1999, 2010) from shallow waters to bathyal depths (McLean 1985, Dantart \& Luque 1994, Roldán \& Luque 2010).

Addisonia enodis Simone, 1996 was described based on three specimens, one of which had soft parts that were dissected and supported the anatomical definition of the species. The main characters that differentiate $A$. enodis from congener species were the lack of radial sculpture, the position of the gill and shell muscle, as well as the shape of the rachidian teeth (Simone 1996: 784). Roldán \& Luque (2010: 209) did not recognize conchological, radular and geographical differences in A. enodis Simone, 1996 for its separation as a different species, considering it a synonym of $A$. excentrica.

The present paper recognizes Addisonia enodis as a valid species and extends its distribution to northeastern Brazil based on specimens found in deep waters off the state of Sergipe. Furthermore, this genus is reported here for the first time associated with an elasmobranch egg capsule from the South Atlantic Ocean.

\section{Material and methods}

The present paper is based on the study of specimens collected by the R/V 'Natureza' using a trawling dredge between 365 to 500 meters depth on the continental slope of the states off Sergipe (northeastern Brazil) as part of benthic studies of the "Programa de Avaliação do Potencial Sustentável de Recursos Vivos na Zona Econômica Exclusiva (REVIZEE/2000-2001)", and specimens collected using a trawling dredge and trawl between 50 to 60 meters depth on the continental shelf of the states off Rio de Janeiro and São Paulo (southeastern Brazil) in 2001 to 2002. Other specimens collected in 1987 by the R/V 'Prof. W. Besnard' from the continental shelf off southeastern Brazil were reexamined (Simone 1996).

Elasmobranch egg capsules were obtained using a trawl net during the pink shrimp fishery on the continental shelf of the state off São Paulo. Capsules were placed in a container with ice and then taken to the Laboratory of Malacology (MZSP - Museu de Zoologia, Universidade de São Paulo, São Paulo, Brazil) for opening and removal of embryos. A living specimen of Addisonia enodis was found inside a capsule and then fixed in $70 \%$ ethanol.

\section{Results}

\section{Addisoniidae Dall, 1882 \\ Addisonia enodis Simone, 1996 (Figure 1)}

\section{Material examined}

Types; BRAZIL, Sergipe: off São Francisco River mount (1041.4'S, $36^{\circ} 18.7^{\prime}$ 'W, dredged, 365 m), 28.X.2000, R/V 'Natureza' col. (MZSP 121236, 2 shells (Figure 1A-B): length 1.62 to $1.84 \mathrm{~mm}$ x width 1.19 to $1.57 \mathrm{~mm} \times$ height 0.96 to $0.99 \mathrm{~mm}$ ). Rio de Janeiro: off Arraial do Cabo (dredged, $50 \mathrm{~m}$ ), 13.IX.2002 (MZSP 35845, 1 specimen: length $4.0 \mathrm{~mm}$ $\mathrm{x}$ width $3.04 \mathrm{~mm}$ x height $0.8 \mathrm{~mm}$ ), (dredged, $107 \mathrm{~m}$ ), 19.II.2002 (MZSP 35846, 1 shell: length $7.74 \mathrm{~mm} x$ width $6.7 \mathrm{~mm}$ x height $3.3 \mathrm{~mm}$ ). São Paulo: off Santos (trawl, 50-60 m), IX.2001 (MZSP 54617, 1 specimen,

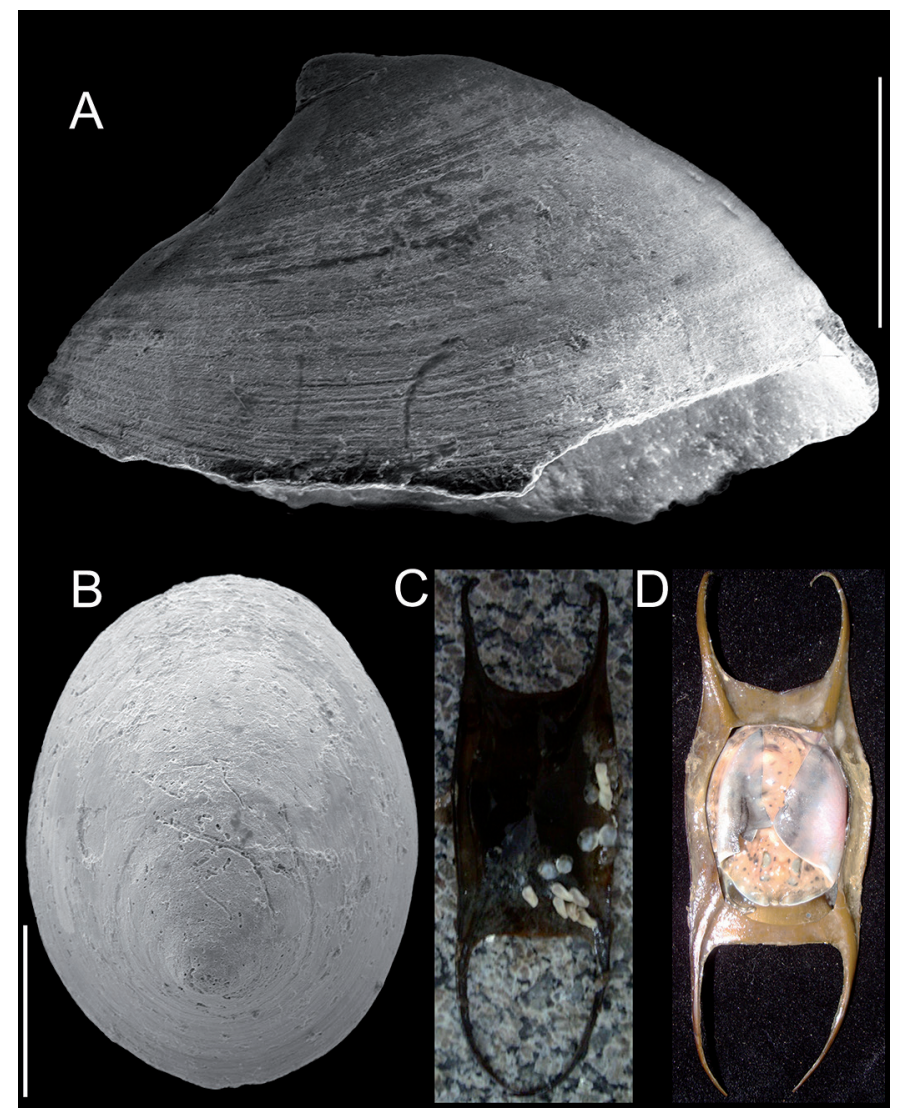

Figure 1. Specimens of Addisonia enodis and ovigerous capsule of Atlantoraja castelnaui. A, lateral view of $A$. enodis (scale $=500 \mu \mathrm{m})$; B, dorsal view of $A$. enodis (scale $=500 \mu \mathrm{m}) ; \mathrm{C}$ and D, ovigerous capsules of Atlantoraja castelnaui in which $A$. enodis were found.

inside capsule of Atlantoraja castelnaui (Ribeiro, 1907) (Figure 1C-D): length $10.5 \mathrm{~mm} \times$ width $8.45 \mathrm{~mm}$ x height $4.3 \mathrm{~mm}$ ).

\section{Ecology}

This species may be found on sand to mud bottoms between 50 to $365 \mathrm{~m}$ depth from Brazilian waters, associated with egg capsules of Atlantoraja castelnaui.

\section{Geographic distribution}

Northeastern (Sergipe state - present study) to Southeastern Brazil (Rio de Janeiro and São Paulo states - Simone 1996).

\section{Discussion}

We believe that conchological, anatomical and radular variations among specimens of $A$. excentrica and $A$. enodis need to be further investigated, especially based on a large sample of Addisonia from Brazilian waters, to ascertain if both species are actually conspecific. In this case, it is important to keep its status as a valid species rather than synonymize them, until further data, including molecular analyses, clarify this issue.

The present paper reports the association of Addisonia with an elasmobranch egg capsule of the family Arhynchobatidae Nelson, 2006 for the first time. Addisonia enodis was found living inside the egg capsule of Atlantoraja castelnaui from Brazilian shallow waters 
(between 50 to $60 \mathrm{~m}$ depth). This skate occurs from the Southeastern Brazil to Argentina waters, usually living between 10 to $100 \mathrm{~m}$ depth, and lay pairs of eggs on sandy or muddy bottoms (Bornatowski \& Abilhoa 2012). Further information is not yet available for $A$. enodis, despite the fact that some of the abovementioned sharks and rays occur along the Brazilian coast.

The samples studied here from the continental slope off northeastern Brazil reinforce the possibility of live specimens of Addisonia being less abundant in deeper waters. It is likely that the specimens usually live in shallower waters (up to $100 \mathrm{~m}$ ) due to greater abundance of elasmobranch egg capsules (especially of skates of the family Arhynchobatidae Nelson, 2006) which are biologically associated. Particularly, Scyliorhinidae, Rajidae, and now Arhynchobatidae, are potential families to find specimens of Addisonia and possibly other gastropods [e.g., Choristella Bush, 1897 (McLean 1992)] associated with their eggs in Brazilian waters based on common records in other eco-regions (McLean 1985, Ragozzi 1985, Villa 1985, Mclean 1992, Dantart \& Luque 1994, Roldán \& Luque 1999, 2010) and the greater richness of known elasmobranchs (especially Rajidae) on the Atlantic Coast of South America.

Most published studies on Addisonia have been based on specimens of $A$. excentrica collected from the north Atlantic and Mediterranean Sea (Dall 1882, 1889a, b, McLean 1985, Dantart \& Luque 1994, Roldán \& Luque 1999, 2010). These studies have shown considerable variability in the shell morphology (Dantart \& Luque 1994), such as specimens with a lowly curved to moderately arched shell (Dall 1889a, b: pl. 25, fig. 1, pl. 44, fig. 11, pl. 63, fig. 100, Abbott 1974: fig. 206, McLean 1985: figs 1, 3, Dantart \& Luque 1994: figs 68-71, Simone 1996: fig. 14, Roldán \& Luque 2010: fig. 6A), while other shells are rather highly arched (McLean 1985: fig. 2); shells with a concentric sculpture poorly developed, bearing obsolete to fine lines (Dall 1889a,b: pl. 25, fig. 1, pl. 44, fig. 11, pl. 63, fig. 100, Abbott 1974: fig. 206, McLean 1985: figs 1-4, Dantart \& Luque 1994: figs 68-69, Roldán \& Luque 2010: fig. 6A) as well as a well-marked ornamentation represented by riblets (Dantart \& Luque 1994: figs 70-72). These studies also show that the species has a variably deflected apex. Furthermore, teleoconch proportions vary considerably: 1.0 to $20.3 \mathrm{~mm}$ in length (McLean 1985, Roldán \& Luque 1999). Specimens measuring $2.6 \mathrm{~mm}$ in length can already act as functional males (Roldán \& Luque 1999) and represent adult shells. This considerable degree of variation appears more an assembly of different species rather than phenotypic plasticity of such a specific environmental strategist, as the samples of $A$. enodis has been more uniform in the shell shape.

Addisonia excentrica has been found living in association with egg capsules of sharks from the family Scyliorhinidae [e.g., Scyliorhinus canicula (Linnaeus, 1758)] and skates from the family Rajidae de Blainville, 1816 [e.g., Raja clavata Linnaeus, 1758 and Raja spp.] (Ragozzi 1985, Villa 1985, Dantart \& Luque 1994, Roldán \& Luque 1999, 2010). Arhynchobatidae, with three known species (Bornatowski \& Abilhoa 2012), Chimaeridae, with three known species, Scyliorhinidae, with seven known species ( $S$. canicula is not reported for Brazil), and Rajidae, with 28 known species (Rosa \& Gadig 2014) are the families (with their respective numbers of species) of oviparous elasmobranchs recorded for the Brazilian coast (Bornatowski \& Abilhoa 2012, Rosa \&
Gadig 2014). In general, members of these groups are demersal, living from the continental shelf down to the continental slope. Females deposit egg capsules on the sea floor and/or attached to structures on the bottom (Ebert \& Stehmann 2013). Addisonia excentrica has been found in egg capsules of S. canicula and Raja Linnaeus, 1758 from the Mediterranean Sea between 47 to 426 m (Ragozzi 1985, Villa 1985, Roldán \& Luque 2010). However, this species is collected more frequently between 50 to 200 m (Dantart \& Luque 1994, Roldán \& Luque 2010).

\section{Acknowledgments}

To Dr. José C. N. Barros (Laboratório de Malacologia, Departamento de Pesca e Aquicultura, Universidade Federal Rural de Pernambuco, Recife, Pernambuco, Brazil) for the donating the specimens of Addisonia for study; to Dr. Carlo M. Cunha (Museu de Zoologia, Universidade de São Paulo) for obtaining the elasmobranch egg capsules and sorting of a living specimen of Addisonia enodis; to the "Laboratório de Microscopia e Microanálise (LAMM/CETENE - Recife, Pernambuco, Brazil)" for the SEM photographs; to biologist Daniel Cavallari (MZSP) by measuring shells; to Dr. Ricardo S. Rosa (Departamento de Sistemática e Ecologia, Universidade Federal da Paraíba, João Pessoa, Paraíba, Brasil), Dr. Santiago M. Quijano (Universidade Estadual Paulista Júlio de Mesquita Filho, São Paulo, Brasil), Dr. Dráusio P. Véras (Laboratório de Oceanografia Pesqueira, Departamento de Pesca e Aqüicultura, Universidade Federal Rural de Pernambuco, Recife, Pernambuco, Brasil), Dr. Carlo M. Cunha (Academy of Natural Sciences of Drexel University, Philadelphia, USA) and Dr. Teodoro V. Junior (Laboratório de Elasmobrânquios, Universidade Estadual Paulista Júlio de Mesquita Filho, São Paulo, Brasil) for help with the information and/or literature on oviparous elasmobranchs; to Dr. Angel Luque (Departamento de Biologia, Universidad Autonoma, Madrid, Spain) for sending publications on Addisoniidae; to Dr. Martin L. Christoffersen (Departamento de Sistemática e Ecologia, Universidade Federal da Paraíba), Dr. Paula Spotorno de Oliveira (Instituto de Estudos do Mar Almirante Paulo Moreira) and the anonymous reviewers for critically reviewing the manuscript; This work was partly supported by a post-doctoral grant from Conselho Nacional de Desenvolvimento Científico e Tecnológico $(\mathrm{CNPq} / \mathrm{DCR})$ and Fundação de Apoio à Pesquisa e à Inovação Tecnológica do Estado de Sergipe (FAPITEC/SE) to Silvio F. B. Lima (proc. \# 300441/2016-9).

\section{References}

ABBOTT, R.T. 1974. American Seashells: The Marine Mollusks of the Atlantic and Pacific Coasts of North America. 2 ed. Van Nostrand Reinhold Company, New York.

BORNATOWSKI, H. \& ABILHOA, V. 2012. Tubarões e raias capturados pela pesca artesanal no Paraná: guia de identificação. Hori Consultoria Ambiental, Curitiba.

BOUCHET, P. \& GOFAS, S. 2014. Addisonia Dall, 1882. World Register of Marine Species (último acesso em 19/01/2015).

DALL, W.H. 1882. On certain limpets and chitons from the deep waters off the eastern coast of the United States. Proc. U. S. Natl. Mus. 4:400-414.

DALL, W.H. 1889a. Reports on the results of dredgings, under the supervision of Alexander Agassiz, in the Gulf of Mexico (1877-78) and in the Caribbean Sea (1879-80), by the U. S. Coast Survey Steamer 'Blake'. Bull. Mus. Comp. Zool. 18:1-492. 
Lima, S.F.B. et al.

DALL, W.H. 1889b. A preliminary catalogue of the shell-bearing marine mollusks and brachiopods of the southeastern coast of the United States, with illustrations of many of the species. Bull. U. S. Natl. Mus. 37:1-221.

DANTART, L. \& LUQUE, A.A. 1994. Cocculiniformia and Lepetidae (Gastropoda: Archaeogastropoda) from Iberian waters. J. Molluscan Stud. 60(3):277-313.

EBERT, D.A. \& STEHMANN, M.F.W. 2013. Sharks, batoids and chimaeras of the North Atlantic. FAO Species Catalogue for Fishery Purposes 7, Food and Agriculture Organization of the United Nations, Rome.

HASZPRUNAR, G. 1987. The anatomy of Addisonia (Mollusca, Gastropoda). Zoomorphology 106(5):269-278.

LEAL, J.H. \& SIMONE, L.R.L. 2000. Copulabyssia riosi, a new deep-sea limpet (Gastropoda: Pseudococculinidae) from the continental slope off Brazil with comments on the systematics of the genus. Nautilus 114(2):59-68.

LIMA, S.F.B. 2014. Notocrater christofferseni n. sp. (Vetigastropoda: Pseudococculinidae): first record of the genus in the South Atlantic Ocean. Zootaxa 3873(2):178-186. http://dx.doi.org/10.11646/zootaxa.3873.2.5

LIMA, S.F.B., GUIMARÃES, C.R.P. \& SIMONE, L.R.L. 2016. Lepetella furuncula sp. nov. (Vetigastropoda: Lepetelloidea): the first species of the genus discovered in the South Atlantic Ocean (northeastern Brazil). Bull. Mar. Sci. 92(2):257-262. http://dx.doi.org/10.5343/bms.2015.1079

McLEAN, J.H. 1985. The Archaeogastropod family Addisoniidae Dall, 1882. Life habit and review of species. Veliger 28(1):99-108.
McLEAN, J.H. 1992. Systematic review of the family Choristellidae (Prosobranchia: Lepetellacea), with description of new species. Veliger 35(4):273-294.

RAGOZZI, A. 1985. A proposito di Addisonia lateralis. Notiziario CISMA '1984' 6:53.

ROLDÁN, E. \& LUQUE, Á.A. 1999. Notes on the reproduction and larval shell of Addisonia excentrica (Tiberi, 1855) (Gastropoda, Cocculiniformia, Lepetelloidea, Addisoniidae). J. Molluscan Stud. 65(4):510-514.

ROLDÁN, E. \& LUQUE, Á.A. 2010. The ecology, biology and taxonomy of Addisonia excentrica (Tiberi, 1855) (Cocculiniformia: Addisoniidae) from Southern Spain. J. Molluscan Stud. 76(3):201-210.

ROSA, R.S. \& GADIG, O.B.F. 2014. Conhecimento da diversidade dos Chondrichthyes marinhos no Brasil: a contribuição de José Lima de Figueiredo. Arq. Zool. 45(esp.):89-109.

SIMONE, L.R.L. 1996. Addisonia enodis, a new species of Addisoniidae (Mollusca, Archaeogastropoda) from the Southern Brazilian Coast. Bull. Mar. Sci. 58(3):775-785.

SIMONE, L.R.L. \& CUNHA, C.M. 2003. Pseudococculina rimula, a new species (Cocculiniformia: Pseudococculinidae) from off southeastern Brazil. Nautilus 117(3):69-77.

VILLA, R. 1985. Note su habitat ed ecologia di Addisonia lateralis (Requien, 1848). Notiziario CISMA ‘1983’6:9-12. 